\title{
TINJAUAN YURIDIS KONSEP MAKAR DALAM PERSPEKTIF HUKUM TATA
}

\section{NEGARA ISLAM}

\author{
Syariful Alam \\ Fakultas Hukum Universitas Muhammadiyah Malang \\ Jl. Raya Tlogomas No. 246 Malang \\ E-mail; syarifulalam@umm.ac.id
}

\begin{abstract}
The treason or treason act is closer to the act of betrayal. In a constitutional law perspective, this treason is defined as the act of a person or group of people towards leadership in a country because of its incompatibility with the rules that apply in the country, so that he or they take actions that tend to "deviate" so that it can break down the leadership of a state leader. In the corner of the desert of Islam, treason or treason act can be done by a person or group of people preceded by a political conspiracy, evil consensus, and intrigue to achieve its political goals. In the Qur'an several verses are mentioned about this treason. Where all contain the notion that treason is an act or an attempt to oppose and undermine the power of someone who is not favored or considered an enemy who has conflicting indications. Both in terms of religion and worldliness by means of deception, deception, or other acts that are contrary to the religion of Islam. Starting from this context, the author wants to review specifications and indications of treason from the perspective of Islamic state governance law by taking the constellation of thoughts of classical scholars.
\end{abstract}

Keywords: Treason, Islamic Constitutional Law, Islamic Politics

\begin{abstract}
Abstrak
Makar atau perbuatan makar lebih dekat kepada tindak pengkhianatan. Dalam sudut pandang ketata negaraan, perbuatan makar ini di artikan sebagai perbuatan seorang atau sekelompok orang terhadap kepemimpinan dalam suatu negara karena ketidak sesuaiannya terhadap aturan yang berlaku di negara tersebut, sehingga ia atau mereka melakukan tindakan yang cenderung "menyimpang" sehingga dapat meruntuhkan kepemimpinan seorang kepala negara. Dari sisi pandang Islam sendiri, perbuatan makar atau tindakan untuk membelot terhadap penguasa dipicu oleh perbuatan yang dilakukan oleh seseorang atau kelompok yang diawali dengan adanya kesepakatan berniat jahat, konspirasi untuk melawan dan indikasi-indikasi menyimpang aturan untuk mencapai tujuan berkuasa. Al-Quran dan al- Hadis jelas-jelas memberikan penjabaran bahwa tindakan makar ini merupakan perbuatan yang dilarangdalam kondisi apapun - dengan cara menentang pada pemerintah yang sah dan terpilih. Baik itu menentang secara tegas maupun secara samar, mengajak seseorang atau golongan untuk melakukan perlawanan terhadap pemimpin - terlepas pemimpin itu adil ataupun tidak. Berawal dari konteks inilah, penulis ingin mengulas tentang spesifikasi dan indikasi makar dari sisi perspektif hukum tata negara Islam dengan mengambil konstelasi pemikiran ulamaulama klasik.
\end{abstract}

Kata Kunci: Makar, Hukum Tata Negara Islam, Politik Islam 


\section{A. PENDAHULUAN}

Konsep-konsep negara yang relatif modern, seperti sekularisasi dan globalisasi, akan memainkan peran dalam pola peta politik dan teologi yang terus menerus digunakan di negara-negara manapun - termasuk negara mayoritas Muslim. Sudah cukup jelas bahwa, sama seperti pandangan diskursif yang berubah sepanjang masa pra-modern, mengingat kondisi geopolitik negara-negara di dunia internasional-masalah seperti pemberontakan, perbedaan pendapat, protes, dan kekerasan politik - akan terus menghasilkan bidang hukum baru dan wacana tentang bagaimana mengatasi masalah ini. ${ }^{1}$

Begitu pula Islam dan politik, tidak bisa dipisahkan satu sama lain, bahkan begitu erat dalam kehidupan bernegara di Indonesia. Konsep politik Islam selalu berlandaskan nilai-nilai dan ajaran-ajaran Islam. Jadi, mustahil jika konsep politik Islam justru terlepas dari ajaranajaran Islam. Meski demikian dalam perjalanan sejarah perpolitikan dan tata negara Islam, sebagai contoh proses pemilihan maupun pemberhentian kepala negara, tidak ada yang baku dalam proses keduanya itu.

Kepala negara tidak lain adalah wakil rakyat dan rakyatlah yang berhak meminta pertanggung jawaban kepada kepala negara dan rakyat pulalah yang mem-bai'at serta berhak pula me-ma'zul-kan (memberhentikan) apabila diperoleh cukup alasan untuk itu. Maka sebagai upaya terciptanya prinsip check and balance, masyarakat memiliki hak untuk mengawasi tindak-tanduk kepala negara itu. Oleh karena itu, apabila kepala negara tersebut melakukan kecurangan atau zalim serta mengabaikan segala ketentuan yang berlaku dan diberlakukan (syari'at atau hukum), maka rakyat berhak menegur ataupun memecatnya. ${ }^{2}$

Perbedaan pendapat, ambisi dan kepentingan masing-masing pihak yang muncul dalam proses interaksi berpolitik tidak menutup kemungkinan akan memicu timbulnya konflik, pertengkaran, pertikaian, penindasan, peperangan dan pembunuhan atau pertumpahan darah, yang pada gilirannya nanti mampu berimplikasi pada terjadinya kehancuran total dalam berbagai dimensi kehidupan umat manusia itu sendiri. ${ }^{3}$

Makar (Bughat) dalam perspektif hukum tata negara Islam adalah golongan yang melawan Khalifah (pemimpin) yang sudah sah dan tidak melakukan sesuatu yang menyalahi ketentuan agama. Fenomena makar masuk dalam soal kepemimpinan politik atau al-imarah. ${ }^{4}$

Tindakan makar baik menurut hukum positif maupun hukum pidana dalam Islam adalah bentuk tindak kriminal yang sangat berbahaya dan juga dikategorikan sebagai kejahatan

\footnotetext{
1 Tasha Solomon, "Law and Theory: Premodern and Contemporary Development of Islamic Discourse on Rebellion", Journal of Mason Graduate Research, No. 3, Vol. 3, 2016, hlm 128.

2 Tengku Muhammad Hasbi Ash-Shiddiqi, Islam dan Politik Bernegara, Pustaka Rizki Putra, Semarang: 2002, hlm. 171

${ }^{3}$ Mujar Ibnu Syarif dan Khamami Zada, Fiqih Siyasah: Doktrin dan Pemikiran Politik Islam, Jakarta, Erlangga: 2008, hlm. 96

4 A. Hasan, Ibn Hajar al-Asqalani: Bulughu al-Maram, Terjemahan Bulughul Maram, Jilid II, Bandung, Diponegoro, 1967, h. 186
} 
politik yang memiliki ciri motif dan tujuan yang berbeda dari kejahatan biasa. Karena tindakan makar ini pada dasarnya adalah konflik vertikal yang terjadi antara rakyat dan penguasa negara, dan demi menciptakan hubungan yang harmonis antara rakyat dan penguasa, pemerintah sebagai pemegang kekuasaan negara harus dapat melaksanakan pemerintahan yang mengedepankan prinsip-prinsip demokrasi, good goverment, melakukan pembangunan yang merata, adil dan makmur di seluruh daerah, serta menanamkan rasa nasionalisme kebangsaan dan persatuan melalui pendidikan bagi seluruh warga negara, dan warga negara itu sendiri juga harus dapat memahami hak dan kewajibannya sebagai warga negara yang baik.

Dalam memprioritaskan tantangan saat ini, faktor-faktor yang harus difokuskan secara berkelanjutan adalah bagaimana mencegah terjadinya bahaya, entah itu terhadap kaum Muslim ataupun non-Muslim, dapat dikurangi dengan penerapan hukum - khususnya hukum Islam yang responsif, dan mekanisme hukum mana yang harus diterapkan untuk meningkatkan kepatuhan dengan hukum dan mencegah ketidakpatuhan yang akan timbul di kemudian hari. $^{5}$

Menilik dari eksplorasi tersebut, penulis tertarik untuk mengulas permasalahan tentang makar dalam perspektif hukum tata negara Islam dan bagaimana negara memberikan kebijakan terkait tindakan makar tersebut.

\section{B. PEMBAHASAN}

\section{Konsep Negara Islam}

Di antara fungsi negara dalam wacana hukum Islam adalah mengawal jalannya roda dakwah Islam agar menjangkau segenap umat manusia. ${ }^{6}$ Syariat Islam tidak membatasi negara dalam sekat-sekat geografis. Bahkan Islam menganggap bahwa pada prinsipnya negara di muka bumi ini adalah merupakan satu kesatuan, karena dakwah Islam merupakan dakwah alamiah (untuk seluruh alam) yang tidak dibatasi oleh batasbatas geografis.

Pengelompokan negara dalam kajian hukum Islam hanya merupakan hasil ijtihad para fukaha, karena kondisi perang yang berkepanjangan antara kaum muslimin dan nonmuslim, yang dalam hal ini adalah Romawi dan Persia. Para fukaha kemudian merasa perlu membuat pola klarifikasi negara agar dapat memastikan hukum yang berkaitan dengan perang dan damai diaplikasikan pada tempat dan situasi yang sesuai. Selain itu, untuk membantu proses lahirnya fatwa dan arahan berdasarkan lingkungan sosial politik yang tepat. Adalah prinsip utama bagi hukum Islam, bahwa kebanyakan hukum syariat-

\footnotetext{
${ }^{5}$ Corri Zoli, M. Cherif Bassiouni, Hamid Khan, "Justice in Post-Conflict Settings: Islamic Law and Muslim Communities as Stakeholders in Transition", Utrecht Journal of International and European Law, No. 55, Vol.33, 2017, hlm. 38.

${ }^{6}$ Olehnya, Ibnu Khaldun memberi definisi bagi khilafah, bahwa ia adalah pengganti dari penentu syari'at (Rasulullah SAW) dalam urusan menjaga agama dan mengatur urusan dunia. Lihat: Ibnu Khaldun, Abdurrahman bin Muhammad, Muqaddimah Ibnu Khaldun, Beirut: Daar al-Fikr dan Kairo: Daar al-Sya'b, hlm. 191
} 
khususnya pembagian negeri-diterapkan dengan mempertimbangkan konteks yang ada (amr al-waqi'). ${ }^{7}$ Oleh karena itu, klasifikasi negara tersebut hanya merupakan hasil ijtihad dan bukan sesuatu yang baku, sehingga ia terhapus dan tidak berlaku dengan selesainya peperangan. ${ }^{8}$

Tariq Ramadhan menulis dalam bukunya To be a European Muslim: "Daar alIslam (negara Islam) dan Daar al-Harb adalah dua konsep yang tidak bisa ditemukan dalam al-Quran dan Sunnah. Keduanya sebenarnya tidak berakar pada sumber dasar Islam yang prinsip-prinsipnya dipersembahkan untuk seluruh dunia (lil-alamin), menembus batas waktu, dan segala batas geografis. Bahkan, hal ini adalah usaha manusia yang dipengaruhi oleh sejarah dengan tujuan untuk mendeskripsikan dunia dan untuk memberi umat muslim suatu standar bagi mengukur dunia dan menyesuaikan diri dengan realitas mereka."9

Untuk memudahkan klasifikasi tersebut, maka dalam perspektif kajian hukum Islam, dikenal pembagian negara sebagai berikut: (a) Negeri Islam (Daar al-Islam); (b) negeri non-Islam (Daar al-Harb); (c) negeri yang mengikat janji (Daar al-Ahdi).

\section{a. Daar al-Islam (Negeri Islam)}

Pada prinsipnya, syariat Islam tidak meletakkan syarat bagi terbentuknya sebuah negara, sebagaimana yang dikenal dalam aturan hukum Internasional dengan Istilah "warga negara". Pembatasan yang sifatnya sempit itu, dalam pandangan syariat Islam, bertolak belakang dengan ke-universal-an Islam yang diturunkan Allah SWT untuk seluruh umat manusia. ${ }^{10}$

Islam menyatukan manusia di atas pondasi akidah yang diyakini oleh umat manusia berdasarkan keridhaan dan ketundukan, lalu meletakkannya sebagai tolak ukur kaum muslimin berkumpul padanya. Oleh karena itu, Allah SWT menegaskan bahwa orang-orang yang beriman itu bersaudara. ${ }^{11}$

Boleh jadi, terminologi negara Islam pertama kali diperkenalkan oleh sahabat Khalid bin al-Walid RA kala mengirim surat kepada penduduk al-Hirah ${ }^{12}$ yang beragama Kristen:

Dan aku jadikan untuk mereka, orang tua renta yang lemah bekerja, orang yang ditimpa musibah, orang kaya yang jatuh miskin hingga orang-orang yang

\footnotetext{
${ }^{7}$ Muhammad Haniff Hasan, Teroris Membajak Islam, Penerbit Grafindo, Jakarta: 2007, hlm. 73. Lihat juga: Umar Ahmad al-Firjani, Ushul al-Ilaqaat al-Dauliyah fi al-Islam, Daar Iqra', Tripoli: 1988, hlm. 20

${ }^{8}$ Umar Ahmad Farjani, Op. Cit., hlm. 21

${ }^{9}$ Muhammad Haniff Hassan, Op. Cit., hlm. 72

${ }^{10}$ Lihat: Ali bin Abdur Rahman al-Thayyar, al-Niza'at al-Dauliyah fi Syari'ah al-Islamiyyah, Huquq al-Thabi'i al-Muallif, Riyadh: 1424 H, hlm. 19

${ }^{11}$ Lihat: QS. Surah al-Hujurat: 10

${ }^{12}$ Kota ini letaknya di pesisir pantai, $3 \mathrm{~km}$ dari Kufah, di tempat yang bernama al-Najaf. Ia merupakan tempat bermukim raja-raja Arab pada masa Jahiliyah yang terkenal adalah al-Nasr, Lakhm al-Nukman, serta pendahulupendahulu mereka. Lihat: Yaquut bin Abdillah al-Hamawi, Mu'jam al-Buldan, Beirut: Daar al-Shadir, 1977, Vol. II, hlm. 328
} 
seagama dengannya bersedekah padanya, aku akan hapuskan jizyah (mereka), dan merekaserta anak keturunannya akan ditanggung oleh Baitul Mal kaum Muslimin, selama mereka masih tinggal di negeri hijrah dan negeri Islam (Daar al-Islam). ${ }^{13}$

Dalam negara Islam berdomisili kelompok-kelompok selain kaum muslimin dari kalangan ahlu dzimmah dan musta'min. ${ }^{14}$ Seluruh penduduk negeri, baik dari kalangan kaum muslimin, ahlu dzimmah, maupun musta'min memperoleh hak jaminan keamanan bagi jiwa, harta dan kehormatannya. Kaum muslimin mendapat jaminan karena keislamannya, ahlu dzimmah lantaran dzimmah mereka, dan musta'min karena (jaminan) keamanan bagi mereka. ${ }^{15}$

Negara dalam perspektif hukum Islam merupakan satu kesatuan selama tetap dinaungi oleh aturan Islam. Wilayahnya membentangi segenap penjuru negeri dan kota yang di dalamnya berdomisili kaum muslimin yang beriman pada agama ini. Intinya, negara Islam itu dapat bermakna setiap tempat yang didiami kaum muslimin dan mereka sanggup menampakkan aturan-aturan Islam. ${ }^{16}$

\section{b. Daar al-Harb (Negeri non-Islam)}

Para sarjana hukum Islam hampir melahirkan sebuah konsensus bahwa negeri kaum yang menyelisihi syari'at Islam dinamakan sebagai "Daar al-Harb" (secara tekstual diartikan sebagai negeri perang). Yang demikian disebabkan perang antara akum muslimin dan kaum nonmuslim yang ramai berkecamuk pada masa-masa suburnya ijtihad fikih, karena agresi-agresi yang sifatnya intens dari musuh-musuh serta pembelaan diri yang dilakukan oleh kaum muslimin. ${ }^{17}$

Melalui pendalaman pendapat para fukaha, dalam pendefinisian negara Islam, terdapat kesepakatan bahwa setiap negeri yang tidak bersedia tunduk pada otoritas kaum muslimin, tidak terealisasi padanya aturan-aturan Islam, hukum yang berlaku adalah hukum non-Islam, serta penduduknya tidak memiliki ikatan perjanjian dengan pemerintahan kaum muslimin, maka ia bukan negeri Islam dan tergolong sebagai negeri al-harb.

Pemicu lahirnya terminologi "Daar al-Harb” ini adalah tatkala negeri-negeri (nonmuslim) menyaksikan syari'at Islam sukses mengurai sekat-sekat dalam bangsabangsa serta berhasil menegakkan pilar persamaan dan keadilan. Di sinilah mereka mulai menyemai permusuhan terhadap syari'at ini. Islam memuliakan setiap pribadi, membebaskan bangsa-bangsa serta mengawal jalannya kebebasan, utamanya

\footnotetext{
${ }_{13}$ Abu Yusuf Ya'qub bin Ibrahim, al-Haraj, Daar al-Ma'rifat li al-Tiba'ah wa an-Nasyr, Beirut: 1979, hlm. 144

${ }^{14}$ Mereka yang mendapat jaminan keamanan dari kaum muslimin selama berdomisili dalam negara Islam

15 Abdul Karim Zaidan, Ahkam al-Dzimmah wa al-Musta'min fi Daar al-Islam, Cet. II, Muassasah ar-Risalah, Beirut: 1982, hlm. 19

${ }^{16}$ Abdul Qadir 'Audah, al-Tasyri' al-Jinaai fi al-Islam, Cet. IV, Daar Ihya at-Turats al-Arabi, Beirut: 1975 , Vol. I, hlm. 295

${ }^{17}$ Muhammad Abu Zahrah, al-Ilaqaat al-Dauliyah fi al-Islam, Daar al-Fikr al-Arabi: Beirut: 1995, hlm. 51.
} 
kebebasan dalam beragama. Hal ini jelas tidak sejalan dengan prinsip kekuasaan absolut pada masa tersebut. Raja-raja pun bersatu memerangi kaum muslimin dimanapun mereka berada. Menghadapi kenyataan ini, kaum muslimin bangkit membela diri dan membalas semisal perlakuan tersebut. Oleh karenanya, penyebutan terminologi "Daar al-Harb" itu menuruti hukum realitas. ${ }^{18}$

Di antara para sarjana hukum Islam kontemporer, ada pula yang mendefinisikan negeri non muslim sebagai negeri yang padanya tidak terdapat otoritas bagi Islam, tidak berlaku aturan Islam, dan tidak mendapat keamanan orangorang yang berada di bawah jaminan keamanan kaum muslimin. ${ }^{19}$

\section{c. Daar al-Ahdi (Negeri yang Mengikat Janji)}

Dalam sejarah disinggung, banyak bangsa dan kabilah yang tidak bersedia menyatakan tunduk secara totalitas kepada kaum muslimin dan tidak terdapat otoritas kaum muslimin pada mereka. Akan tetapi, mereka terikat dalam sebuah ikatan perjanjian dengan kaum muslimin, dengan tetap mempertahankan eksistensi kepemilikan mereka atas negeri sendiri, kendati kepemimpinan tersebut berlaku tidak absolut.

Kesepakatan damai yang terjalin antara kaum muslimin dan non-muslim ini terselenggara baik sebelum maupun setelah perang dan penaklukan. Sebab, dalam syari'at perang, kaum muslimin tidak dibenarkan melancarkan serangan terhadap musuh melainkan setelah mengetengahkan kepada mereka tawaran agama Islam, atau membayar jizyah (upeti atau pajak), atau kemudian perang. Sebagai preferensinya, mereka mengikat perjanjian dengan kaum muslimin menurut syaratsyarat yang disepakati bersama. Akan tetapi, syarat-syarat tersebut berbeda menurut kondisi masing-masing negeri atau kabilah, juga berdasarkan pada besar atau kecilnya kebutuhan mereka terhadap bantuan dan pertolongan Daulah Islamiyah.

Golongan yang mengikat perjanjian itu terbagi atas tiga: ahlu al-dzimmah, ahlu al-hudnah, dan ahlu al-aman. Sementara lafadz al-dzimmah dan al-ahdu pada asalnya mencakup seluruh golongan tersebut. ${ }^{20}$

Jika perjanjian itu sifatnya permanen yakni akad dzimmah, maka dibebankan atas kaum nonmuslim kewajiban membayar jizyah yang diserahkan kepada negeri Islam sebagai jaminan keamanan. Dalam kondisi ini, maka negeri mereka (Daar alAhdi) dikategorikan dengan Daar al-Islam, apakah perjanjian tersebut lahir dari

\footnotetext{
${ }^{18}$ Ali Ali Manshur, al-Syari'ah al-Islamiyyah wa al-Qanun al-Dauli al-Aam, Al-Majlis al-A'la li Syu'un alIslamiyyah, Kairo: 1965, hlm. 275.

${ }^{19}$ Lihat: Muhammad Abu Zahrah, al-Ilaqaat al-Dauliyah fi al-Islam, Op. Cit., hlm. 53. Lihat pula: Abdul Wahab Khallaf, al-Siyasah al-Syar'iyah, Op. Cit., hlm. 81.

${ }^{20}$ Ibnu Qayyim al-Jauziyyah, Ahkam Ahli al-Dzimmah, Tahqiq: Subhi al-Shalih, Cet. III, Beirut: Daar al-Ilmi li al-Malayin, Beirut: 1983, Vol. II, hlm. 475.
} 
kesepakatan setelah perang atau sejak awal sebelum perang sesuai kesepakatan kedua belah pihak.

Dari paparan di atas, dapat ditarik beberapa kesimpulan:

1) Jika negeri itu tunduk pada aturan Islam sebagaimana keadaan negeri $\mathrm{Najran}^{21}$ yang beragama kristen pada masa Nabi SAW, maka ia merupakan bagian dari Daar al-Islam, karena kekuatan dan otoritas berada di tangan kaum muslimin. ${ }^{22}$

2) Jika pada negeri tersebut tidak diimplementasikan aturan Islam di dalamnya, maka ia dikategorikan sebagai Daar al-Muwada'ah dengan syarat menyerahkan pajak kepada kaum muslimin. Sebab, aturan Islam belum tampak dan menguasai di dalamnya, disamping otoritas kaum muslimin padanya belum final. ${ }^{23}$

\section{Definisi Makar Menurut Ulama}

Dalam definisi syara'-seperti yang telah dijelaskan dalam nash-nash Al-Qur`an dan As-Sunnah-makar memiliki varian definisi dalam berbagai mazhab fiqih, meskipun berdekatan maknanya atau ada unsur kesamaannya. Kadang para ulama mendefinisikan makar secara langsung, terkadang pula mendefinisikan tindakannya, yaitu al-baghyu (pemberontakan).

Ulama Hanafiyah berpendapat: "Makar adalah keluar dari ketaatan kepada imam (pemimpin) yang haq (sah) dengan tanpa alasan haq (benar). Dan para pelaku makar adalah orang yang keluar dari ketaatan kepada imam yang haq (sah) dengan tanpa haq (dibenarkan)., 24

Menurut Ulama Malikiyah: "Makar adalah mencegah diri untuk mentaati orang yang telah sah menjadi imam (pemimpin) dalam perkara bukan maksiat dengan menggunakan kekuatan fisik (mughalabah) walaupun karena alasan ta wil (penafsiran agama)... Dan pelaku makar adalah kelompok (firqah) dari kaum muslimin yang

\footnotetext{
${ }^{21}$ Najran adalah negeri yang memiliki banyak pohon kurma dan tumbuh-tumbuhan lainnya, berdekatan dengan kota Shan 'a, yakni antara And dan Hadramaut yang letaknya sekitar gunung-gunung. Lihat: Abul Abbas Ahmad bin Ali al-Qalqayandi, Nihayah al-Arb fi Ma'rifah al-Ansaab al-'Arab, Vol. I, hal. 7. Di negeri inilah tempat kejadian kisah Ashabul Ukhdud yang sangat masyhur sebagaimana diceritakan oleh Allah SWT, dalam alQur'an surah al-Buruuj.

${ }^{22}$ Nabi membuat nota kesepakatan damai dengan penduduk Najran serta memberi jaminan keamanan bagi jiwa dan harta mereka dan segala bentuk gangguan, baik yang berasal dari kaum muslimin maupun dari selain mereka. Di samping itu, Nabi SAW menetapkan atas mereka sebagai imbalan dari fasilitas yang diberikan, kewajiban berupa harta. Ada yang berpendapat bahwa kewajiban tersebut adalah kharaj, namun ada pula dari kalangan ulama yang mengatakan ia adalah Jizyah. Lihat: Abu Yusuf bin Ibrahim, Op. Cit., hlm. 72

${ }^{23}$ Contohnya adalah negeri-negeri al-Naubah (negeri-negeri sepanjang aliran sungai Nil, dari Mesir hingga Sudan) yang tetap menjaga eksistensi daulah mereka selama kurun abad yang panjang. Pada masa Khalifah Utsman bin Affan RA., Abdullah bin Abi al-Sarh membuat nota kesepakatan damai dengan penduduk alNaubah, agar mereka menyerahkan kepada kaum muslimin sebanyak tiga ratus ekor pada setiap tahunnya selain dari jizyah, dengan kompensasi kaum muslimin mendistribusikan kepada mereka bahan makanan yang senilai dengan apa yang mereka berikan. Lihat: Ibnu Asakir, Tarikh al-Damasqi, Cet. I, Beirut: Daar al-Fikri, 1998, Vol. XXX, hlm. 529

${ }^{24}$ Muhammad Amin Ibnu Abidin, Hasyiyah Ibnu Abidin, Riyadh, Dar Alam Al-Kutub, Juz III, hlm. 426
} 
menyalahi pemimpin atau wakilnya, untuk mencegah haknya yang wajib mereka tunaikan, atau untuk menggantikannya.,"25

Menurut Ulama Syafi'iyah: "Pelaku makar adalah kaum muslimin yang menyalahi imam dengan jalan memberontak kepadanya, tidak mentaatinya, atau mencegah hak yang yang seharusnya wajib mereka tunaikan (kepada imam), dengan syarat mereka mempunyai kekuatan (syaukah), ta`wil, dan pemimpin yang ditaati (muthaa') dalam kelompok tersebut.",26

Ulama Hanabilah berpandangan: Pelaku makar adalah orang-orang yang melakukan pemberontakan kepada seorang pemimpin-walaupun ia bukan pemimpin yang adil-dengan ta`wil yang diperbolehkan (ta`wil sa`igh), mempunyai kekuatan (syaukah), walaupun pemimpin yang ada di antara mereka bukan pemimpin yang ditaati perintahnya. $^{27}$

Sedangkan Ulama Zhahiriyah berargumen: "Pelaku tindak makar adalah orangorang yang menentang pemimpin adil dalam melaksanakan kekuasaannya, kemudian mereka merampas harta zakat serta menjalankan hukuman hudud (sanksi denda)",28

Dengan menilik beberapa definisi tersebut, terlihat bahwa perbedaan yang ada disebabkan adanya perbedaan syarat-syarat yang harus terpenuhi agar suatu golongan bisa dikategorikan sebagai pelaku tindak makar. Misalnya, menurut ulama Syafi'iyah, syarat makar haruslah karena ta`wil yang fasid (rusak), yaitu memiliki interpretasi yang salah dalam memaknai nash. ${ }^{29}$

Adapun ulama Zhahiriyah, makar diinterpretasikan dengan bisa saja karena kesalahan dalam men-ta wil atau hanya karena alasan-alasan keduniawian, spesifiknya hanya untuk memperoleh harta benda atau kekuasaan. ${ }^{30}$

Sedangkan syarat tersebut, dalam penjelasan ushul fiqih, maksudnya adalah ada syarat syar'iyyah (syarat menurut hukum agama), bukan syarat aqliyyah (syarat menurut akal) atau syarat 'aadiyah (syarat menurut adat). ${ }^{31}$

Jadi syarat itu sebenarnya merupakan hukum syara' (bagian hukum wadh'i), dan itu semua wajib berlandaskan pada dalil-dalil syar'i, semisal wudhu-yang menjadi salah satu syarat sahnya shalat-berdasar pada Q.S Al-Maidah: 6. Jadi, agar mudah memahami definisi yang paling kuat (rajih), atau menjelaskan definisi yang jami an-meliputi semua kandungan yang memang harus ada dalam definisi-dan mani'an-mencegah

\footnotetext{
${ }^{25}$ Muhammad al-Zarqaniy, Syarh al-Zarqaniy 'ala Muwattha' Imam Malik, Dar al-Ma'rifah, Bairut: 1978, hlm. 60

${ }^{26}$ Syamsuddin Muhammad ar-Ramli, Nihayatul Muhtaj, Riyadh, Dar Alam Al-Kutub, Juz. VIII, hlm. 382

${ }^{27}$ Imam al-Zamakhsyari, Syarh al-Muntaha ma'a al-Kasysyaf al-Qana', Cet. ke-2, Mesir, Daar al-Ma'arif, Juz. IV, hlm. 114

${ }^{28}$ Ibnu Hazm al-Andalusy, Al-Muhalla, Mesir, Dar al-Ma'arif, Juz. XII, hlm. 520

${ }^{29}$ Zakariya al-Anshori, Asna al-Mathalib, Beirut, Darul Kutb Ilmiyah, Juz. IV, hlm.111.

${ }^{30}$ Ibid, hlm. 97-98

${ }^{31}$ Imam Asy Syathibi, Al-Muwafaqat, Riyadh, Dar Ibnul Qayyim, Juz. I, hlm. 186
} 
semua yang tidak boleh ada dalam definisi, dan menjadi keharusan untuk meneliti dalildalil syar'i yang melatar belakangi terbentuknya pengertian makar terlebih dahulu.

Dalil-dalil pembahasan tentang makar, adalah Q.S Al-Hujurat ayat 9:

Dan kalau ada dua golongan dari mereka yang beriman itu berperang hendaklah kamu damaikan antara keduanya! tapi kalau yang satu melanggar perjanjian terhadap yang lain, hendaklah yang melanggar perjanjian itu kamu perangi sampai surut kembali pada perintah Allah. kalau dia Telah surut, damaikanlah antara keduanya menurut keadilan, dan hendaklah kamu berlaku adil; Sesungguhnya Allah mencintai orang-orang yang berlaku adil. "32

Selain itu pula terdapat beberapa hadits Nabi SAW yang menjelaskan tentang pemberontakan terhadap pemimpin (imam). Sebagian ulama juga ada yang mengelompokkan dalil dari hadits ini dalam bab-bab tertentu; seperti Imam Ash-Shan'ani merangkumnya dalam bab Qitaal Ahl Al-Baghiy, dimana bab ini terdapat dalam karyanya Subulus as-Salam. Kemudian Abdul Qadir Audah memberikan penjelasan dalam bab an-Nushush al-Waaridah fil Baghy dalam kitabnya yang berjudul Al-Tasyrii' al-Jina ¿iy al-Islaamiy. Selain dari dalil-dalil syara', dalam memaknai tentang makar juga dapat mempertimbangkan data-data tentang sejarah para sahabat yang mengalami pemberontakan, sebagai misal Khalifah Ali bi Abi Thalib dalam Perang Shiffin dan Perang Jamal. Hal ini telah ada konsensus para sahabat (ijma' shahabah) mengenai keharusan memerangi para pelaku makar ini. ${ }^{33}$

\section{Syarat Pelaku Makar}

Kemudian untuk memahami nash-nash syara' yang telah dijelaskan, dapat diambil kesimpulan bahwa terdapat 3 (tiga) syarat yang wajib terpenuhi secara bersamaan dalam sebuah kelompok yang akan diklaim sebagai pelaku makar; melakukan pemberontakan kepada pemimpin atau imam yang sah, memiliki kekuatan yang memungkinkan mampu untuk melakukan tindakan makar sebagai upaya mendominasi (saytharah), memanfaatkan senjata sebagai cara untuk mewujudkan semua tujuan politiknya. ${ }^{34}$

Syarat pertama, melakukan perbuatan melawan kepada khalifah, imam atau pemimpin (khuruuj 'alal imam). Dalam masalah ini bisa saja terjadi dengan ketidak taatan golongan tertentu terhadap kebijakan khalifah atau dengan menolak hak-hak khalifah yang semestinya ditunaikan kepada khalifah tersebut, sebagai contoh masalah pembayaran zakat. Syarat yang pertama ini, terdapat dalam Q.S Al-Hujurat: 9, meskipun tidak secara eksplisit dijelaskan "Dan jika dua golongan dari orang-orang mukmin berperang, maka damaikanlah antara keduanya. Jika salah satu dari kedua golongan itu berbuat aniaya (zalim) maka perangilah golongan yang berbuat aniaya itu sehingga golongan itu kembali kepada perintah Allah ...".

${ }^{32}$ DEPAG, Al-Qur'an Dan Terjemahannya, Departemen Agama RI (Al Waah), Jakarta: Tanpa Tahun,

${ }^{33}$ Zakariya Al-Anshari, Fathu al-Wahhab, Juz II, Daar Ihya`al-Kutub al-Arabiyyah, Indonesia, hlm. 153

${ }^{34}$ Abdurrahman Al-Maliki, Nizham Al-Uqubat. Cet. Ke-2, Darul Ummah, Beirut, hlm. 79 
Kendati demikian, Syaikh al-Imam al-Islam Zakariya al-Anshariy dalam kitabnya Fathul Wahhab menjelaskan bahwa; "Ayat ini memang tidak menyebutkan 'melawan kepada khalifah atau pemimpin' secara jelas dan terang (sharih), namun ayat tersebut telah mencakup berdasar pada keumuman (mujmal) ayatnya, bisa pula dikarenakan ayat tersebut menuntutnya. Dan apabila perang dilakukan karena adanya kezhaliman satu golongan pada golongan lainnya, bisa dipastikan kezhaliman satu golongan atas pemimpin tentu akan lebih dituntut lagi." 35

Konklusinya, penjelasan pada syarat pertama ini (pemberontakan terhadap pemimpin) merupakan universalitas (mujmal) dari ayat tersebut (Q.S 49: 9). Disamping itu, adanya syarat tersebut ditunjukkan secara komprehensif dalam hadits yang memaparkan tercelanya tindakan pemberontakan kepada pemimpin, khalifah atau imam (khuruj 'ani tha'at al-imam). Sebagai dalilnya sesuai dengan sabda Nabi SAW:

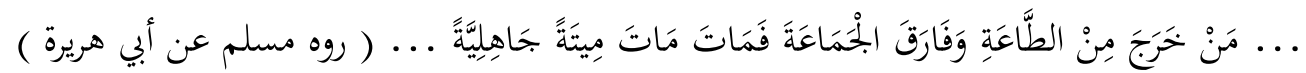

"Barangsiapa yang keluar dari ketaatan (kepada pemimpin) dan memisahkan diri dari jamaah kemudian mati, maka matinya adalah mati jahiliyyah. ",36

Beberapa hadits Nabi SAW yang membahas masalah makar (bughat), demikian halnya, juga membahas tentang perilaku menentang kepada pemimpin atau khalifah, bukan tentang masalah lain. Sebagaimana halnya pemberontakan yang bergejolak dalam Perang Shiffin, dimana Muawiyah sebagai pemimpin pasukan untuk melawan Khalifah Ali bin Abi Thalib yang mana saat itu posisinya sebagai khalifah yang sah, dalam konteks ini pemerintahannya mutlak sebagai pemerintah yang sah. ${ }^{37}$

Dengan demikian, pemberontakan kepada kepala negara yang sah, misalnya kepada presiden dalam sistem republik, kepada raja dalam sistem monarkhi, atau kepada pimpinan dalam sistem yang sah, dari sisi pandang manapun, adalah perilaku makar dalam pengertian syara'.

Syarat yang kedua, memiliki kekuatan dan sangat memungkinkan kelompok makar tersebut bisa melakukan dominasi terhadap kekuasaan yang sah. Kekuatan tersebut sudah harus tertata sedemikian rupa, sehingga mampu mengajak suatu kelompok atau golongan yang melakukan makar dapat kembali taat pada pemimpin yang sah, dan seorang pemimpin sudah seharusnya mengerahkan segala kesanggupan dan kemampuannya, contohnya dengan kemauan mengeluarkan dana besar, mempersiapkan pasukanpasukannya, dan mengantisipasi jika terjadi peperangan.

Dalam hal ini, adapun makna kekuatan, sering diungkapkan oleh para ahli fiqih dengan istilahasy-syaukah, dikarenakan salah satu makna asy-syaukah bisa juga

\footnotetext{
${ }^{35}$ Zakariyya Al-Anshari, Fathul Wahhab, hlm. 153

${ }^{36}$ Imam Muslim, Shahih Muslim, Riyadh, Dar al-Kutb Ilmiyyah, No. 3436

${ }^{37}$ Muhammad 'Abdurrauf al-Munawi, Faidh al-Qadr: Syarh al-Jami' al-ShaghirDaar al-Ma'rifat, , Beirut, Juz. II, hlm. 336
} 
dimaknai al-quwwah atau al-ba`s (keduanya sama-sama memiliki arti kekuatan). ${ }^{38}$ Sedangkan para ulama Syafi'iyyah memberikan rincian bahwa asy-asyaukah bisa terlaksana apabila ada jumlah orang yang banyak (al-katsrah) dan memiliki kekuatan (al$q u w w a h)$, juga memiliki pemimpin yang dipatuhi dan ditaati.

Hal ini jelas memberikan isyarat bahwa terdapat sekumpulan orang yang loyal, bersatu padu, solid, tertata dan pada akhirnya melahirkan sebuah kekuatan. Selain itu pula, Taqiyudin al-Husainy dalam bukunya Kifayat al-Akhyar yang mengulas tentang syarat kekuatan, beliau memaparkan; "...bila yang melakukan pemberontakan itu adalah afraadan (individu), akan tetapi mudah mendisiplinkan mereka, maka mereka itu bukanlah termasuk tindakan melawan (bughat). ${ }^{, 39}$ Dengan demikian jelas sudah, bila ada yang melakukan indikasi makar kepada seorang pemimpin yang sah, namun tidak memiliki kekuatan apapun, misal hanya dilakukan oleh satu atau beberapa individu yang tidak membentuk dan memiliki kekuatan, maka ini tidak dikategorikan sebagai tindakan makar.

Syarat ketiga, mempergunakan kekuatan senjata demi untuk merealisasikan semua tujuan-tujuannya. Para ahli fiqih memberikan penjelasan mengenai syarat penggunaan senjata dengan istilah man'ah, atau terkadang juga disebut dengan istilah asysyaukah, sebab asy-syaukah juga bisa bermakna ash-shilaah (senjata). Sedangkan Man'ah (atau biasa juga dibaca mana'ah) memiliki arti lain yaitu al- 'izz (kemuliaan) dan al-quwwah (kekuatan), atau memiliki kemampuan serta kekuatan yang dapat digunakan untuk menghalangi orang lain yang mempunyai maksud jahat terhadapnya. ${ }^{40}$

Dalil pada syarat yang ketiga ini dijelaskan dalam ayat tentang makar dalam Q.S Al Hujurat: 9, yaitu pada lafaz اقْتََكُوا (dua golongan yang saling berperang). Dalam ayat ini mengindikasikan adanya sarana yang diperebutkan dalam perang itu, yaitu as-shilaah (senjata). Selain dalil tersebut, terdapat dalil-dalil lainnya, yaitu hadits Nabi SAW "Barangsiapa yang membawa senjata untuk memerangi kami, maka ia bukanlah golongan kami.",41

Dari penjelasan di atas jelaslah bila ada golongan yang melawan dan tidak mentaati pemimpin, namun tidak memanfaatkan senjata, dengan kata lain hanya melalui kritikankritikan atau protes dengan pernyataan-pernyataan ketidak setujuan terhadap pemerintah, maka kelompok itu masih belum bisa dikategorikan makar.

Berlandaskan semua pemaparan tersebut, jelaslah bahwa definisi makar adalah golongan atau kelompok yang terpenuhi 3 (tiga) syarat secara lengkap, yaitu: (a) Melakukan perlawanan terhadap pemimpin, imam atau khalifah yang sah, (b) Memiliki kekuatan yang teindikasi mampu melakukan tindak makar untuk mendominasi

38 Ibrahim Anis, et.al, Al-Mu'jamu al-Wasith, Cet. Ke-2, Daar al-Ma'arif, Kairo, hlm. 501

${ }^{39}$ Taqiyuddin Al-Husainiy, Tanpa Tahun, Kifayatu al-Akhyar, Toha Putera, Semarang, Juz II, hlm. 167

40 Al-Mu'jamul Wasith, hlm. 888

${ }^{41}$ Shahih Muslim, No. 143. 
kekuasaan, dan (c) Memanfaatkan kekuatan senjata untuk bisa mewujudkan hegemoni politiknya.

Hal serupa juga dapat didefinisikan sebagai syarat di atas, jika yang menjadi korban makar adalah pemimpin yang adil. Syarat semacam ini tidaklah tepat, dikarenakan ayatayat tentang makar bersifat mutlak dan absolut, tidak ada persyaratan spesifik bahwa pelaku makar adalah kelompok atau orang yang melawan pada pemimpin yang adil saja. Selain itu, beberapa hadits Nabi SAW yang menjelaskan tentang makar juga bersifat mutlak (baik pemimpin yang adil dan maupun fasik), dan ini bukan dalil muqayyad (hanya spesifik pada pemimpin yang adil saja).

\section{Makar di Indonesia}

Munculnya tindak pidana makar di Indonesia, berdasar realitas yang ada, kendati tidak terlepas dari adanya protes, perlawanan ataupun munculnya gejolak-gejolak ekonomi, sosial, penegakan hukum, maupun konstelasi politik di dalam negeri. Sedangkan mengenai alasan individu atau golongan itu melakukan makar, terdapat banyak faktor yang melatar belakanginya, akan tetapi pada umumnya adalah rasa ketidak puasan terhadap pelaksanaan roda pemerintahan yang sedang berjalan.

Tindakan-tindakan tersebut lazimnya dilakukan oleh sekelompok orang atau golongan yang mempunyai tujuan dan maksud yang sama. Selain itu pula tidak menutup kemungkinan dilakukan oleh satu atau dua individu saja, yang memicu timbulnya ketidak senangan publik dan berimplikasi pada ujaran-ujaran kebencian, sindiran politis dan fitnah vertikal pada kebijakan-kebijakan pemerintah, meski realitasnya itu hanya belandaskan pada syahwat politik yang cenderung membabi buta.

Dahulu di Indonesia diatur ketentuan mengenai masalah kegiatan subversi dalam Undang-Undang Nomor 11/PnPs/Tahun 1963 Tentang Pemberantasan Kegiatan Subversi. ${ }^{42}$ Dilihat dari definisinya, makar memiliki pengertian yang sama dengan definisi subversi yaitu: gerakan bawah tanah untuk menggulingkan pemerintahan yang sah.

Undang-Undang Nomor 11 / PnPs / Thn. 1963 Tentang Pemberantasan Kegiatan Subversi ini terkenal perundang-undangan 'karet' dan merupakan 'jala tak berujung' yang dapat menjerat siapapun juga. Dan sanksi hukuman untuk pelaku yang melakukan tindak pidana subversi ini tergolong berat.

Oleh karena itu, undang-undang ini telah dihapuskan pada zaman pemerintahan yang dipimpin oleh Prresiden B.J. Habibie. Dengan alasan yang disebutkan: ${ }^{43}$

a. Bahwa hak asasi manusia sebagai anugerah Tuhan Yang Maha Esa secara kodrati melekat pada diri manusia, meliputi antara lain hak memperoleh

${ }^{42}$ Undang-Undang Nomor 11/PnPs/Thn. 1963 Tentang Pemberantasan Kegiatan Subversi

${ }^{43}$ Undang-Undang Republik Indonesia Nomor 27 Tahun 1999 tentang Perubahan Kitab Undang-Undang Hukum Pidana yang Berkaitan dengan Kejahatan Terhadap Keamanan Negara 
kepastian hukum dan persamaan kedudukan di dalam hukum, keadilan dan rasa aman, hak mengeluarkan pendapat, berserikat dan berkumpul serta meningkatkan kesejahteraan masyarakat berdasarkan Pancasila dan UndangUndang Dasar 1945.

b. Bahwa Undang-Undang Nomor 11 / PnPs / Thn. 1963 Tentang Pemberantasan Kegiatan Subversi bertentangan dengan hak asasi manusia dan prinsip negara yang berdasarkan atas hukum serta menimbulkan ketidakpastian hukum, sehingga dalam penerapannya menimbulkan ketidak adilan dan keresahan di dalam masyarakat.

Berdasar pada penjelasan mengenai tindak pidana makar tersebut sangatlah jelas bahwa melawan terhadap pemerintahan yang sah merupakan sebuah pelanggaran berat. Meskipun begitu, bukan berarti pemerintah melarang rakyat untuk melayangkan kritik, asalkan mengikuti aturan dan juga kritik yang dilontarkan merupakan kritik yang membangun demi keberlangsungan kehidupan bernegara yang adil dan transparan, tidak menutup kemungkinan pemerintah akan memberikan apresiasi baik, mendukung dan membenahi sistem yang lebih mengedepankan kemaslahatan rakyatnya.

Terlepas dari ini semua, setiap manusia memiliki hak dan kebebasan untuk mengekplorasikan opini dan keinginannya, selama tidak menyalahi aturan dan tatanan yang berlaku dalam pemerintahan negara maka masih sangat bisa ditolerir eksistensi tindakan tersebut.

\section{PENUTUP}

Dalam pandangan hukum tata negara Islam, makar dikategorikan sebagai kejahatan luar biasa yang dilakukan oleh sekelompok orang yang sudah tidak taat lagi kepada pemimpin yang sah. Karena memang dipandang sebagai suatu kejahatan yang serius, bahkan para ulama - baik ulama mazhab dan ulama khala $f$ (kontemporer) - pun memberikan konsensus argumentatif mengenai kejahatan makar ini, yang pada esensi konklutif-nya melarang kejahatan tindakan makar yang dimaksudkan untuk menggulingkan pemerintahan yang sah, karena lebih banyak menimbulkan masalah dan kerugian yang besar dari pada mendatangkan manfaatnya. Dan sebagai sanksi untuk pelaku makar, hukum pidana Islam tegas memberi hukuman mati jika syarat-syarat makar telah terpenuhi.

\section{DAFTAR PUSTAKA}

\section{Buku}

A. Hasan, Ibn al-Hajar al-Asqalani: Bulughu al-Maram, Terjemahan Bulughul Maram, Jilid II, Bandung: 1967.

Abdul Karim Zaidan, Ahkam al-Dzimmah wa al-Musta'min fi Daar al-Islam, Cet. II, Muassasah ar-Risalah, Beirut: 1982.

Abdul Qadir 'Audah, al-Tasyri' al-Jinaai fi al-Islam, Cet. IV, Vol. I, Daar Ihya at-Turats alArabi, Beirut: 1975, 
Abdurrahman Al-Maliki, Nizham Al-Uqubat. Cet. Ke-2, Darul Ummah, Beirut: 1990.

Abu Yusuf Ya'qub bin Ibrahim, al-Haraj, Daar al-Ma'rifat li al-Tiba'ah wa an-Nasyr, Beirut: 1979.

Abul Abbas Ahmad bin Ali al-Qalqayandi, Nihayah al-Arb fi Ma'rifah al-Ansaab al- 'Arab, Vol. I.

Ali Ali Manshur, al-Syari'ah al-Islamiyyah wa al-Qanun al-Dauli al-Aam, Al-Majlis al-A'la li Syu'un al-Islamiyyah, Kairo: 1965.

Ali bin Abdur Rahman al-Thayyar, al-Niza'at al-Dauliyah $f i$ Syari'ah al-Islamiyyah, Cet. I, Riyadh: Huquq al-Thabi'i al-Muallif, $1424 \mathrm{H}$.

DEPAG, Al-Qur'an Dan Terjemahannya, Departemen Agama RI (Al Waah), Jakarta: Tanpa Tahun.

Ibnu Asakir, Tarikh al-Damasqi, Cet. I, Vol. XXX, Daar al-Fikri, Beirut: 1998.

Ibnu Hazm al-Andalusy, Al-Muhalla, Dar al-Ma'arif, Mesir: Tanpa Tahun,

Ibnu Khaldun, Abdurrahman bin Muhammad, Muqaddimah Ibnu Khaldun, Daar al-Fikr Daar al-Sya'b, Beirut: Kairo:

Ibnu Qayyim al-Jauziyyah, Ahkam Ahli al-Dzimmah, Tahqiq: Subhi al-Shalih, Cet. III, Vol. II, Daar al-Ilmi li al-Malayin, Beirut:1983.

Ibrahim Anis, et. al, Mu’jamu al-Wasith, Vol. 2, Daar al-Maarif, Kairo: 1972.

Imam al-Zamakhsyari, Syarh al-Muntaha ma'a al-Kasysyaf al-Qana', Cet. ke-2, Dar alMa'arif, Mesir: 1986.

Imam Asy-Syatibi, TT, Al-Muwafaqaat fi al-Ushuuli al-Ahkaam, Daar al-Fikr, Beirut:

Imam Muslim, Tanpa Tahun, Shahih Muslim, Dar al-Kutb Ilmiyyah, Riyadh:

Muhammad 'Abdurrauf al-Munawi, Faidh al-Qadr: Syarh al-Jami' al-Shaghir, Darul Ma'rifat, Beirut: 1972,

Muhammad Abu Zahrah, al-Ilaqaat al-Dauliyah fi al-Islam, Daar al-Fikr al-Arabi, Beirut: 1995.

Muhammad al-Zarqaniy, 1978, Syarhu al-Zarqaaniyi 'ala al-Muwaththa' li Imam al-Malik, Daar al-Ma'rifaat, Beirut: 1978.

Muhammad Amin Ibnu Abidin, Hasyiyah Ibnu Abidin, Dar Alam Al-Kutub, Riyadh: Tanpa Tahun.

Muhammad Haniff Hasan, Teroris Membajak Islam, Penerbit Grafindo, Jakarta: 2007.

Muhammad Khair Haikal, Jihad wa al-Qitaal fi as-Siyaasah asy-Syar'iyyah, Vol. 2, Beirut, Daar al-Bayaariq, Beirut: 1996. 
Mujar Ibnu Syarif dan Khamami Zada, Fiqih Siyasah: Doktrin dan Pemikiran Politik Islam, Erlangga, Jakarta: 2008.

Syaikh Ali Belhaj, Fashlu al-Kalami fi al-Muwajjahati al-Zhulmi al-Hukkaam, Daar al'Uqubaat, Beirut: 1994.

Syamsuddin Muhammad ar-Ramli, Nihayatul Muhtaj, Dar Alam Al-Kutub, Riyadh: Tanpa Tahun.

Taqiyuddin Al-Husainiy, Kifayatu al-Akhyaar, Juz II, Mathba'ah Toha Putera, Semarang: Tanpa Tahun.

Tengku Muhammad Hasbi Ash-Shiddiqi, Islam dan Politik Bernegara, Pustaka Rizki Putra, Semarang: 2002.

Umar Ahmad al-Firjani, Ushul al-Ilaqaat al-Dauliyah fi al-Islam, Cet. II, Tripoli: Daar Iqra', 1988

Yaquut bin Abdillah al-Hamawi, Mu'jam al-Buldan, Vol. II, Daar al-Shadir, Beirut: 1977.

Zakariya Al-Anshari, Fathul Wahhab, Juz II, Indonesia, Dar Ihya` Al-Kutub Al-Arabiyah, Tanpa Tahun

Zakariya al-Anshori, Asna al-Mathalib, Darul Kutb Ilmiyah, Beirut: Tanpa Tahun.

\section{Jurnal}

Corri Zoli, M. Cherif Bassiouni, Hamid Khan, "Justice in Post-Conflict Settings: Islamic Law and Muslim Communities as Stakeholders in Transition", Utrecht Journal of International and European Law, No.55, Vol.33, 2017.

Tasha Solomon, "Law and Theory: Premodern and Contemporary Development of Islamic Discourse on Rebellion”, Journal of Mason Graduate Research, No. 3, Vol. 3, 2016.

\section{Peraturan Perundang-undangan}

Undang-Undang Nomor 11/PnPs/Tahun 1963 Tentang Pemberantasan Kegiatan Subversi

Undang-Undang Republik Indonesia Nomor 27 Tahun 1999 tentang Perubahan Kitab Undang-Undang Hukum Pidana yang Berkaitan dengan Kejahatan Terhadap Keamanan Negara 